\title{
Description and distribution of the larvae of two species of Fistulariidae (Teleostei, Syngnathiformes) in the southeastern Brazil
}

\author{
Fernanda Bernardo Anacreto Gomes de Barros ${ }^{1}$, Márcia Salustiano de Castro $^{1}$ \& \\ Ana Cristina Teixeira Bonecker ${ }^{1,2}$ \\ Biota Neotropica $v 7(n 1)$ - http://www.biotaneotropica.org.br/v7n1/pt/abstract?article +bn03107012007 \\ Recebido em 30/08/05 \\ Versão reformulada recebida em 30/09/06 \\ Publicado em 21/03/07 \\ ${ }^{1}$ Departamento de Zoologia, Instituto de Biologia, Universidade Federal do Rio de Janeiro, \\ CCS, Bloco A, Ilha do Fundão, CEP 21941-590, Rio de Janeiro, Brazil \\ e-mail:mscastro@biologia.ufrj.br,nandauerj@yahoo.com.br \\ ${ }^{2}$ Corresponding author: Ana Cristina Teixeira Bonecker, e-mail: ana@biologia.ufrj.br
}

\begin{abstract}
Barros, F.B.A.G, Castro, M.S. \& Bonecker, A.C.T. Description and distribution of the larvae of two species of Fistulariidae (Teleostei, Syngnathiformes) in the Southeastern Brazil. Biota Neotrop. Jan/Apr 2007 vol. 7 , no. 1 http://www.biotaneotropica.org.br/v7n1/pt/abstract?article+bn03107012007 ISSN 1676-0603.

Fistulariidae contains the single genus, Fistularia, with four species. Two of these species are recorded from Brazil: Fistularia petimba and F. tabacaria. This study describes larvae of these two species of Fistularia, recording their distribution along the southeastern Brazilian coast, which is limited in the north by Real River $\left(12^{\circ} \mathrm{S}\right)$ and in the south by São Tomé Cape $\left(22^{\circ} \mathrm{S}\right)$. Samples were collected using a bongo net with mesh apertures of 330 and $500 \mu \mathrm{m}$ during three oceanographic cruises conducted on spring/98 (Central III), winter/99 (Bahia 1) and autumn/00 (Central IV). The net was towed obliquely and the maximum depth was $200 \mathrm{~m}$. Larvae of $F$. petimba were the most abundant and most widely distributed within the study area, including the seamounts of the Vitória-Trindade Ridge. Larvae of $F$. tabacaria were recorded only between $14^{\circ} \mathrm{S}$ and $21^{\circ} \mathrm{S}$.

Keywords. Fistularia petimba, Fistularia tabacaria,, distribution, fish larvae, southeastern brazilian coast

\section{Resumo}

Barros, F.B.A.G, Castro, M.S. \& Bonecker, A.C.T. Descrição e distribuição das larvas de duas espécies da família Fistulariidae (Teleostei, Syngnathiformes) no sudeste do Brasil. Biota Neotrop. Jan/Apr 2007 vol. 7 , no. 1 http://www.biotaneotropica.org.br/v7n1/pt/abstract?article+bn03107012007 ISSN 1676-0603.

A família Fistulariidae é composta por um único gênero, Fistularia, com quatro espécies; duas delas ocorrem na costa brasileira: Fistularia petimba e F. tabacaria. Este estudo descreve as larvas dessas duas espécies de Fistularia, registrando suas distribuições ao longo da costa sudeste brasileira, que é delimitada ao norte pelo Rio Real $\left(12^{\circ} \mathrm{S}\right)$ e ao sul pelo Cabo de São Tomé $\left(22^{\circ} \mathrm{S}\right)$. As amostras foram coletadas através de uma rede bongô com aberturas de malha de 330 e $500 \mu \mathrm{m}$ durante três operações oceanográficas realizadas na primavera/98 (Central III), inverno/99 (Bahia 1) e outono/00 (Central IV). Os arrastos foram oblíquos até a profundidade máxima de $200 \mathrm{~m}$. As larvas de F. petimba foram as mais abundantes, distribuindo-se por toda a área de estudo, incluindo os montes submersos do sistema Vitória-Trindade. Por outro lado, as larvas de F. tabacaria foram coletadas apenas entre as latitudes $14^{\circ} \mathrm{S}$ e $21^{\circ} \mathrm{S}$.
\end{abstract}

Palavras-chave: Fistularia petimba, Fistularia tabacaria, distribuição, larvas de peixe, costa sudeste brasileira. 


\section{Introduction}

Fistulariids are widely distributed in tropical and subtropical waters of the world. All species are marine, occurring in shallow waters of the seas (Fritzsche 1976, Nelson 1994). The long tubular snout is an adaptation for feeding among reefs (Nelson 1994).

Fistulariidae contains the single genus, Fistularia, with four species. Fritzsche (1976) reviewed the cornetfishes and the relationships of these four species. According with this author, it is possible to define two groups of species based on morphological characteristics and on their distribution.

Fistularia commersonii Rüppell (1838) and F. corneta (Gilbert $\&$ Starks 1904) occur in the Indo-Pacific and in the Eastern Pacific Ocean, respectively. Fistularia petimba Lacepède (1803) occurs in the Tropical Atlantic, Indo-West-Pacific region, Australia and Hawaii; while F. tabacaria Linnaeus (1758) has been recorded in the Tropical Atlantic (Fritzsche 1976). Along the Brazilian coast, adults of F. petimba and F. tabacaria have been recorded in the southeast and south regions, and also near rocky reef sites (Figueiredo \& Menezes 1980, Nunan 1992, Figueiredo et al. 2002).

This is the first published account of the occurrence of Fistularia larval along the Brazilian coast. Also included are the descriptions of the two species of Fistularia recorded from this area and analysis of their distributions.

\section{Material and Methods}

The material used in this study is part of the Brazilian Program "Assessment of the Sustainable Yield of the Living Resources in the Exclusive Economic Zone" (REVIZEE). Sampling stations were distributed along the Brazilian coast, between Real River $\left(12^{\circ} \mathrm{S}\right)$ and São Tomé Cape $\left(22^{\circ} \mathrm{S}\right)$, totaling 330 stations during three oceanographic cruises: spring/98 (Central III), winter/99 (Bahia 1) and autumn/00 (Central IV) (Figure 1).

Ichthyoplankton was collected through oblique hauls using a bongo net (mesh apertures of 330 and $500 \mu \mathrm{m}$ ), up to $200 \mathrm{~m}$ deep (see Castro \& Bonecker 2005 for detailed information about the study area and the sampling methodology).

The characters used to identify Fistulariidae larvae were based in Moser \& Charter (1996) and Ditty et al. (2005): dorsal and anal fin positions, pigment pattern, preanal distance, head and snout length. Measurements of standard length (SL) were taken from the tip of the upper jaw to the end of the hypural with a micrometer ruler (0.1 mm precision).

Larval stages were categorized according to the state of notochord flexion: preflexion, flexion and postflexion stages (Richards, 2006).

All larvae were deposited in the larval fish collection of the Zooplankton and Ichthyoplankton Integrated Laboratory of Federal University of Rio de Janeiro - Brazil (DZUFRJ).

\section{Results and Discussion}

A total of 64 larvae of Fistularia were analyzed (41 of F. petimba and 23 of $F$. tabacaria). All development stages were observed for both species, except the postflexion stage that was not observed to F. tabacaria (Table 1).

During the preflexion stage, F. petimba larvae have long slender body, and the snout is short with pigments from its beginning to the eye. The finfold is still present. The gut is long and its end is close to the dorsal fin origin. The ventral region of the body has small spots of pigment extending to the caudal peduncle (Figure 2a). This pigment pattern was observed in all development stages.

In flexion, the first rays of pectoral, dorsal and anal fins begin to form. The dorsal and anal fin bases are in opposition. The snout becomes longer and tubular with pigment scattered over it. Head spination begins to form with small supra-occipital ridge and serrations on the snout. The two inner rays of the caudal fin are well developed. The gut is long and ends close to the anal fin origin.

During the postflexion, the larvae resemble an adult. The forebrain bone ridges are completely formed, and the snout is very serrated. Pectoral, anal, dorsal and caudal fin rays are formed and the inner rays caudal are longer (Figure $2 b$ ).

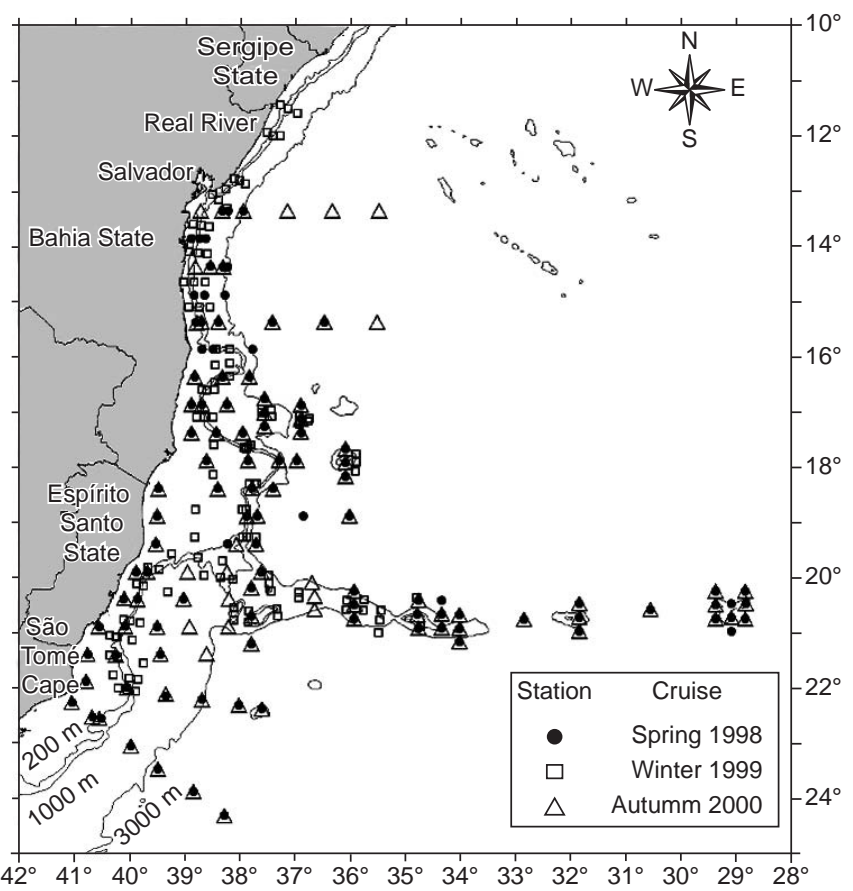

Figure 1. Study area indicating the main geographical features and stations location during the three oceanographic cruises.

Figura 1. a) Área de estudo destacando os principais acidentes geográficos; e b) a localização das estações durante as três operações oceanográficas. 
Fistularia tabacaria larvae have a short gut comprising 1/3 of the standard length during preflexion. Pigment is present along the ventral margin of the body extending from gut to the caudal peduncle (Figure 3a). This pattern occurs in all larval development stages. Pigment is also scattered over the short snout. In preflexion stage, dorsal and anal fin rays begin to form and as in F. petimba, their bases are also in opposition (Figure 3b). However, the dorsal and anal fin bases of F. tabacaria are longer than in F. petimba (Table 1).

During the postflexion, fin rays are completely formed and the inner caudal fin rays are long.

Larvae of Fistularia petimba were widely distributed within the study area, including the seamounts of the Vitória-Trindade Ridge (Figure $4 \mathrm{a}$ ), but larvae of $F$. tabacaria were recorded only between $14^{\circ} \mathrm{S}$ and $21^{\circ} \mathrm{S}$ (Figure $4 \mathrm{~b}$ ).

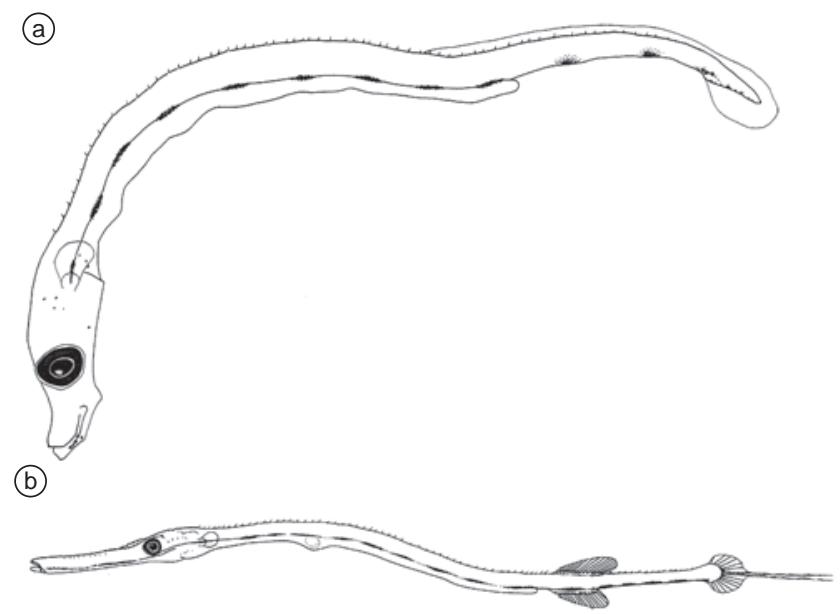

Figure 2. a) Preflexion (DZUFRJ 1397; $9.0 \mathrm{~mm}$ ) and b) flexion (DZUFRJ 10320; $20.0 \mathrm{~mm}$ ) larvae of Fistularia petimba.

Figura 2. Larvas de Fistularia petimba em a) pré-flexão (DZUFRJ 1397; 9,0 mm) e b) flexão (DZUFRJ 10320; 20,0 mm).

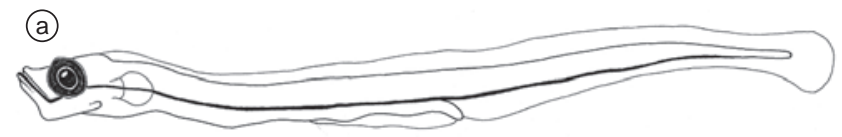

(b)

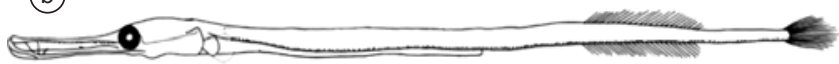

Figure 3. a) Preflexion (DZUFRJ 377; $6.0 \mathrm{~mm}$ ) and b) flexion (DZUFRJ 2663; $17.0 \mathrm{~mm}$ ) larvae of Fistularia tabacaria.

Figura 3. Larvas de Fistularia tabacaria em a) pré-flexão (DZUFRJ 377; $6,0 \mathrm{~mm}$ ) e b) flexão (DZUFRJ 2663; 17,0 mm).
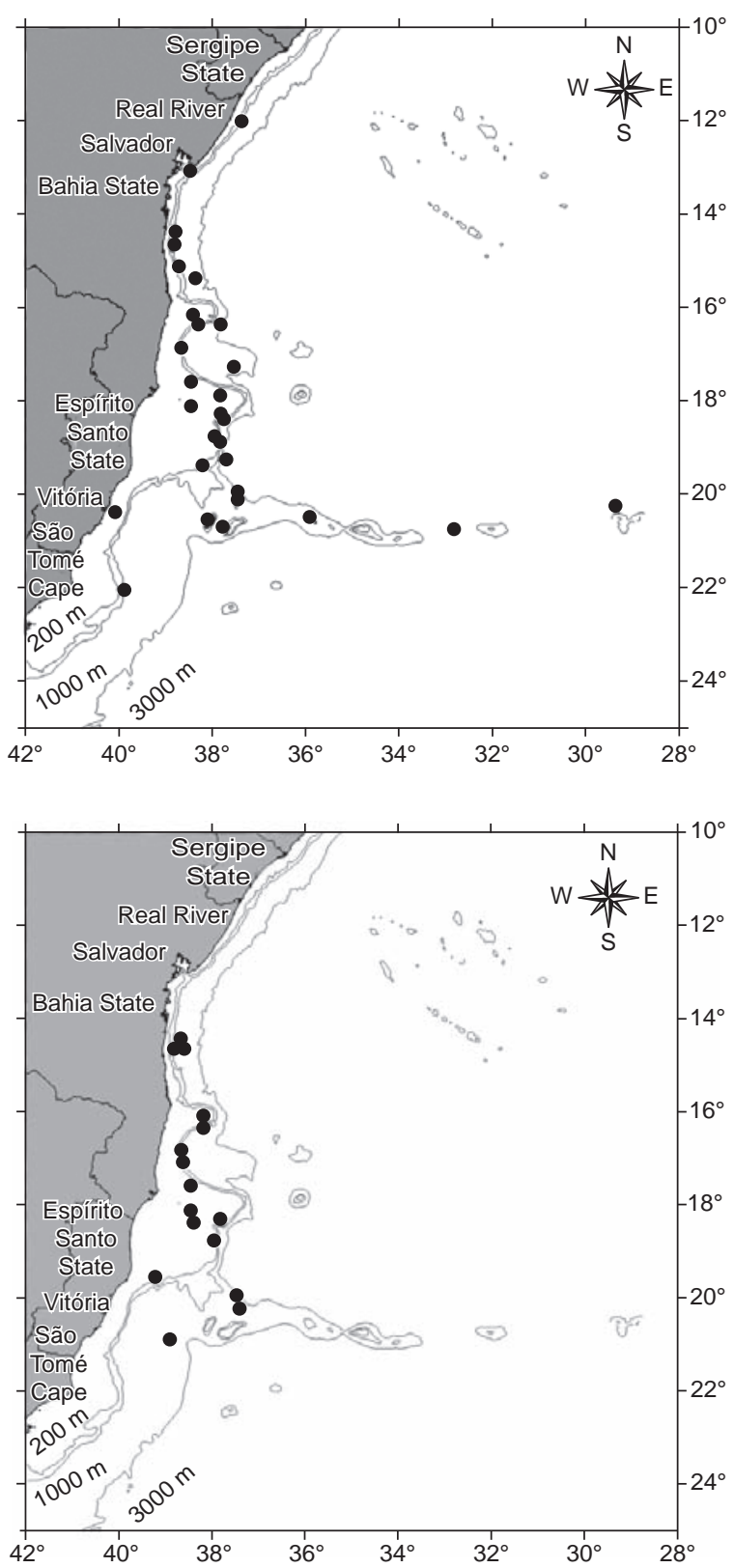

Figure 4. Distribution of Fistularia petimba a) and F. tabacaria b) larvae along the southeastern Brazilian coast.

Figura 4. Distribuição das larvas de Fistularia petimba a) e F. tabacaria b) ao longo da costa sudeste brasileira.

Table 1. Comparative measurements (mm) of Fistularia petimba and F. tabacaria collected along the southeastern Brazilian coast.

Tabela 1. Comparação das medidas (mm) dos diferentes estágios de desenvolvimento de $F$. petimba e $F$. tabacaria coletados ao longo da costa sudeste brasileira.

\begin{tabular}{|c|c|c|c|c|c|}
\hline & \multicolumn{3}{|c|}{ F.petimba } & \multicolumn{2}{|c|}{ F. tabacaria } \\
\hline & Preflexion & Flexion & Postflexion & Preflexion & Flexion \\
\hline $\mathrm{N}$ & 28 & 9 & 3 & 11 & 4 \\
\hline Standard length & $6.5-16.5$ & $17.0-26.5$ & $55.0-64.0$ & $6.0-12.5$ & $13-21.0$ \\
\hline Head length & $1.0-3.5$ & $3.5-7.0$ & $15.0-19.0$ & $1.0-2.5$ & $3.0-4.0$ \\
\hline Snout length & $0.5-2.2$ & $2.5-4.0$ & $12.0-14.0$ & $0.5-1.5$ & $1.5-2.5$ \\
\hline Pre-anal distance & $4.0-9.0$ & $9.0-12.5$ & $19.0-23.0$ & $4.0-5.0$ & $5.0-6.0$ \\
\hline Dorsal and anal fins base length & 0.5 & $0.5-1.5$ & $1.5-2.5$ & $1.0-1.5$ & $1.5-2.0$ \\
\hline
\end{tabular}

$\mathrm{N}=$ number of specimens identified 
According to the literature F. petimba also occurs along the Brazilian south coast while $F$. tabacaria is recorded from the southern and south coasts (Figueiredo \& Menezes, 1980, Figueiredo et al. 2002, Menezes et al. 2003).

\section{Acknowledgments}

The authors thank the team of Zooplankton and Ichthyoplankton Integrated Laboratory of Universidade Federal do Rio de Janeiro for assistance during the field surveys; Sérgio Bonecker and Ronald Fritzsche for comments on manuscript; and Rafael B. de Moura for the drawing. This study was supported by the Executive Committee, Interministerial Commission for Marine Resources (SECIRM), Ministry of Environment (MMA), Sectoral Plan for Marine Resources. Additional support was provided by Coordenação de Aperfeiçoamento de Pessoal de Nível Superior grant (CAPES).

\section{References}

CASTRO, M.S. \& BONECKER, A.C.T. 2005. Leptocephali collected off the eastern coast of Brazil $\left(12^{\circ}-23^{\circ} \mathrm{S}\right)$. Zootaxa 935:1-28.

DITTY, J.G., KILFOYLE, K. FAROOGI, T. \& SHAW. R.F. 2005. Order Syngnathiformes: Families Aulostomidae, Centriscidae, Fistulariidae. In: Early Stages of Atlantic Fishes: An Identification Guide for the Western North Atlantic. (W. J. Richards, ed.). CISC Press, Boca Raton, Florida, 2:1121-1132.

FIGUEIREDO, J.L. \& MENEZES, N.A. 1980. Manual de peixes marinhos do sudeste do Brasil. II. Teleostei (1). Museu de Zoologia, Universidade de São Paulo.

FIGUEIREDO, J.L., SANTOS, A.P. dos, YAMAGUTI, N., BERNARDES, R.A. \& ROSSI-WONGTSCHOWSKI, C.L.D.B. 2002. Peixes da Zona Econômica Exclusiva da Região Sudeste-Sul do Brasil. Levantamento com Rede de Meia Água. Editora da Universidade de São Paulo, São Paulo.
FRITZSCHE, R.A. 1976. A review of the cornetfishes, genus Fistularia (Fistulariidae) with a discussion of intrageneric relationships and zoogeography. Bulletin of Marine Science 26(2):196-204.

MENEZES, N.A., BUCKUP, P.A., FIGUEIREDO, J.L. \& MOURA, R.L. de. 2003. Catálogo das espécies de peixes marinhos do Brasil. Museu de Zoologia, Universidade de São Paulo, São Paulo, 160 p.

MOSER, H.G. \& CHARTER, S.R. 1996. Fistulariidae: Cornetfishes. In: The Early Stages of Fishes in the California Current Region. (H.G. Moser, ed.). La Jolla, Calcofi. Atlas no. 33:718-723.

NELSON, J.R. 1994. Fishes of the World. John Wiley \& Sons. $3^{\text {rd }}$ edition.

NUNAN, G.W. 1992. Composition, species distribution and zoogeographical affinities of the Brazilian reef-fish fauna. Ph.D. Thesis. University of Newcastle upon Tyne. United Kingdom.

RICHARDS, W.J. 2006. Early Stages of Atlantic Fishes. An Identification Guide for the Western Central

Título: Description and distribution of the larvae of two species of Fistulariidae (Teleostei, Syngnathiformes) in the southeastern Brazil.

Author: Barros, FBAG, Castro, MS e Bonecker, ACT

Biota Neotropica, Vol.7 (número 1): 2007

http://www.biotaneotropica.org.br/v7n1/pt/abstract?article+ bn03107012007

Data Received 30/08/05 - Revised 30/09/06

Accepted 21/03/07

ISSN 1676-0603 